\title{
TEACHING VOCABULARY BY USING SUBSTITUTION AND CUED RESPONSE DRILLS TECHNIQUE TO THE EIGHTH GRADE STUDENTS OF SMP NEGERI 41 MEDAN
}

\author{
Romasta Situmorang, Viator Lumban Raja, Fiber Yun Almanda Ginting \\ Catholic University of Saint Thomas \\ Email : fiber_ginting@ust.ac.id
}

\begin{abstract}
In learning a language, the first thing people should learn is vocabulary. Vocabulary is one of the essential aspects of language. Without vocabulary nothing can be conveyed. In other words, vocabulary is the core of the language itself. The aim of this study is to find out whether or not Substitution and Cued Response Drills Technique gives improvement on students' vocabulary mastery. The subject of the study is the students of Class VIII E of SMP Negeri 41 Medan in the Academic Year of 2017/2018. Vocabulary test, questionnaire, observation sheet and field notes were used as the instruments for collecting data. The results of the study showed the improvement of the students' vocabulary mastery. It is proven by the students' mean score of each test: pre test is 45.37 , formative test is 58.28 and post test is 70.12 . Moreover, the improvement could also be seen from the Minimum Mastery Criteria (Kriteria Ketuntasan Minimum) that showed the percentage of students' score of pre test is $9.37 \%$, formative test is $31.25 \%$, and post test is $56.25 \%$. It can be concluded that there is a progress on student score percentage namely $46.88 \%$ from pre-test to post-test based on KKM. Therefore, the application of Substitution and Cued Response Drills Technique is suitable to teach vocabulary to the students.
\end{abstract}

\section{Keywords: vocabulary, substitution and cued response drills technique}

\section{INTRODUCTION}

\subsection{The Background of the Study}

As an international language, English is very important to learn. In Indonesia, English is learned as a foreign language. English as a foreign language is different from that as a second language. As a foreign language, it means that English is not used in daily life, whereas as a second language, it is used in daily life. Consequently, learning English in the context as a second language is easier than that in the context as a foreign language. In learning a language, the first thing people should learn is vocabulary.

As Wilkins (in Thornbury, 2002:13) says that without grammar very little can be conveyed, without vocabulary nothing can be conveyed. It means that vocabulary is the most fundamental aspect in learning a language. Napa (1991:20) states that there are many ways which can be used to develop students' vocabulary achievement. Memorizing some words is the one way to learn vocabulary but it needs a process. In this way, teaching vocabulary will be more useful and enable the students to reach the vocabulary of target language as much as they can.

Based on the writer's interview with the English teacher at SMP Negeri 41 Medan, it was found out that most of the students of SMP Negeri 41 Medan had a

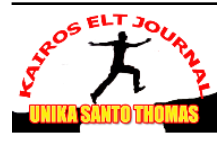


problem in mastering English vocabulary. The same problem was also found when the writer did Teaching Practice Program (TPP). Most of the students were confused when she spoke English in the classroom. They just knew a few English vocabularies. The problem was caused by their way in mastering the vocabulary namely by memorizing the words only from the lists that they have made without practicing them and then they forgot them soon. The students also had low motivation when they learned English. They said that English was difficult. Thus, the students' vocabulary mastery needs a process to make sure that the new words remain in the students' mind. Choosing the right techniques in teaching activity can make the process of learning interesting.

In teaching a language, especially in vocabulary aspect, teachers can use substitution drill technique and cued response drill technique. Substitution drill is a technique that the language learners are required to replace one word with another. They may replace a word of the model sentence with a pronoun, number, or gender, and make some necessary changes (Setiyadi, 2006:63). In this technique, the students may replace the word with other new words according to the teacher's instructions. This technique makes the students active while learning teaching process, because they learn to arrange the structure directly to respond to the teacher's question based on the cue. These two techniques can be combined at the same time in order to improve vocabulary mastery and minimize the monotonous ways in teaching learning English vocabulary.

Based on the explanation, the writer intends to conduct a research entitled "Teaching Vocabulary by Using Substitution and Cued Response Drills Technique to the Eighth Grade Students of SMP Negeri 41 Medan. The writer chose SMP Negeri 41 Medan as the location of the research because there has never been a research like this before at the school.

\section{REVIEW OF LITERATURE \\ 2.1 Vocabulary}

Generally, vocabulary is number of words used for communication. According to Neuman \& Dwyer (2009:385), vocabulary refers to the words we must know to communicate effectively: words in speaking (expressive vocabulary) and words in listening (receptive vocabulary). In addition, Mallery (1944:1) states that our vocabulary is the stock of words on which we can draw in expressing ourselves. In this way, the more words we know the easier we understand what people say and express our thoughts to others.

\subsubsection{Kinds of Vocabulary}

According to Nation (2001: 24), there are two kinds of vocabulary in relation to the language skills of reading, listening, speaking, and writing. They are receptive and productive vocabulary. These two activities are communicative acts, direct and indirect.

Haycraft (in Hatch and Brown, 1995:370) also states that there are two kinds of vocabulary namely receptive vocabulary and productive vocabulary.

In relation to kinds of vocabulary, Nation (2001:13) states that there are four categories of vocabulary in the non-fiction text, they are:

1) High frequency words. These words are almost $80 \%$ of the running words in the text.

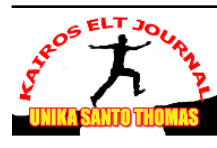


2) Academic words. Typically, these words make up about $9 \%$ of the running words in the text.

3) Technical words. These words make up about 5\% of the running words in the text. It is used by people working in a specialized field.

4) Low-frequency words. These are the words of moderate frequency that does not manage to get into the high-frequency list. They make up over $5 \%$ of the words in an academic text.

\subsubsection{Vocabulary Mastery}

Allen (2000:856) states that mastery is skill or knowledge that makes one master of a subject. Subject in this case is vocabulary in a foreign language which is learnt by students. In addition, Willis (2008:80) says that when students build vocabulary mastery, they can more effectively communicate their ideas, knowledge and voice.

Mastering vocabulary does not necessarily only remembering its spoken and written form. Thornburry (2002: 15) also emphasizes that in the most basic level, someone is said already knowing a word when he/she knows its form and its meanings.

\subsection{Substitution and Cued Response Drills Technique}

In order to introduce words to the students, substitution and cued response drills technique can be used. Setiyadi (2006:63) states that substitution drill is a technique in which the language learners are required to replace one word with another. They may replace a word of the model sentence with a pronoun, number, gender, and make some necessary changes. Cued response drill is a technique that provides language learners with a cue before or after question (Setiyadi, 2006:64).

In implementing substitution drill, the students may replace the word with other new words according to the teacher's instruction. In substitution technique, the students repeat the sentence pronounced by the teacher except the word that has to be substituted. This technique also helps the students to learn the structure of the sentence while learning vocabulary. The following are the examples of substitution drill technique. T represents the teacher and $\mathrm{S}$ represents the students.

Examples:

1. T: My mother is a lawyer.

$\mathrm{T}$ : $\underline{\text { minister }} \quad$ (The students substitute lawyer into minister)

$\mathrm{S}$ : My mother is a minister.

2. T: I go to zoo.

T: park

S: I go to park.

(The students substitute zoo into park)

In implementing cued response drill, the teacher gives a question to the students and giving a cue. Then the students respond to the teacher's question after they catch the cue that the teacher meant. This technique makes the students active while learning teaching process, because they learn to arrange the structure directly to respond to the teacher's question based on the cue. The following are the examples of cued response drill technique. T represents teacher and $\mathrm{S}$ represents students.

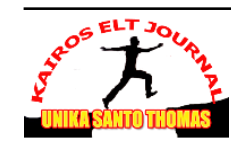


Examples:

1. T: What is your father? (a mechanic)

$\mathrm{S}$ : My father is a mechanic.

T: What does he do? (repairs machines)

$\mathrm{S}$ : He repairs machines.

2. T: Where does your mother work? (hotel)

S: She works in a hotel.

These two techniques can be combined at the same time in order to improve vocabulary mastery and minimize the monotonous ways in teaching learning English vocabulary. The following are the examples of substitution and cued response drills technique. T represents teacher and $\mathrm{S}$ represents students.

Examples:

1. T: I often go to library.

T: church

\section{$\underline{\text { (substitution) }}$}

S: I often go to church..

$\mathrm{T}$ : What is library? (a place where books are kept)

S: Library is place where books are kept.

$\mathrm{T}$ : What is church? ( a place of worship for Christians) (cued response)

$\mathrm{S}$ : Church is a place of worship for Christians.

2. T: Tini is a novelist.

T: clerk

\section{$\underline{\text { (substitution) }}$}

S: Tini is a clerk.

T: As a novelist, what does Tini do? (writes novels) $\quad$ (cued response)

S: As a novelist, Tini writes novels.

In line with the scope of the study, the vocabulary aspect that was taught is words relate with occupations, places, and animals.

\section{RESEARCH METHOD}

\subsection{Research Design}

This research is a classroom action research which is intended to find out how well the substitution and cued response drills technique in teaching vocabulary to the eighth grade students of SMP Negeri 41 Medan in the Academic Year of 2017/2018. The data of this study are quantitative and qualitative data. The quantitative data will be collected by using written test. Further, the qualitative data will be collected by using observation sheet and field notes. In classroom action research, there are four major steps. They are planning, action, observation and reflection.

\subsection{The Location and Time of the Study}

This study was conducted at SMP Negeri 41 Medan which is located at $\mathrm{Jl}$. Bunga Ncole No 129 Medan Tuntungan. The reason for choosing this school is because there is no similar research which has ever been conducted at this school. This study was conducted in August 2017.

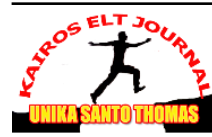




\subsection{The Subject of the Study}

The subject of this study is the eighth grade students of SMP Negeri 41 Medan. There are seven classes of the eighth grade students which consist of class A, B, C, D, E, F and G. The writer chooses class E as the subject of this study which consists of 32 students, 18 males and 14 females. The reason for choosing this class is that the students in this class are the lowest of all in English according to their teacher. The teacher said that the students of class E have the lower score than the students of other classes.

\section{DATA ANALYSIS AND DISCUSSION \\ 4.1 Data Analysis}

In this study, there are two kinds of data collected, they are quantitative and qualitative data. The quantitative data were taken from the students' vocabulary score which collected through test (pre-test, formative test, and post-test) and questionnaire. Every cycle was conducted in three meetings in addition to pre-test and post-test. Pre-test was done before meeting I of Cycle I and formative test was done at the end of cycle I. Meanwhile, post-test was done after meeting III of cycle II finished. The data analysis showed the process of improving students' vocabulary by using Substitution and Cued Response Drills Technique and the improvement of the students' vocabulary score. The qualitative data were taken from the observation sheet and field notes which described an event that occurred while conducting the study.

\subsection{Discussion}

Substitution and Cued Response Drills Technique was applied to teach vocabulary to $8 \mathrm{E}$ students of SMP Negeri 41 . The writer concluded that the use of Substitution and Cued Response Drills Technique could be the effective way to help students in learning vocabulary. It was shown in histogram 4.4, in which the mean score of each test was improved. The mean score of pre-test was 45.37, formative test was 58.28, and the post-test was 70.12. Those scores showed that cycle II was better than cycle I.

The improvement can be also seen from the percentage of students who got score $\geq 70$. In pre-test, there were 3 students $(9.37 \%$ ) who got score $\geq 70$, in formative test, there were 10 students $(31.25 \%)$ who got point $\geq 70$ and in the posttest there were 18 students $(56.25 \%)$ who got point $\geq 70$. However, there was about $43.75 \%$ students who got point $\leq 70$. Besides that, the improvement can be seen in the observation sheet, field notes, and questionnaire. Most of the students were active and enthusiastic when the technique was applied during the teaching and learning process that started from cycle I to cycle II.

In conclusion, Substitution and Cued Response Drills Technique was suitable to teach vocabulary to the students because this technique gave students a chance to improve their vocabulary. The students are also demanded to be more active and give their best attention when they learn vocabulary so that they can master vocabulary as many as possible. As the result, they will have a good stock of vocabularies. On the other hand, the students' test scores improved in both cycles after being taught by using Substitution and Cued Response Drills Technique. In addition, the questionnaire also showed that all students agreed with the using of Substitution and Cued Response Drills Technique. Furthermore, they gave their

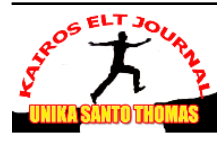


attention during the teaching and learning process. They were enthusiastic and interested in learning vocabulary during the meetings.

\section{CONCLUSIONS AND SUGGESTIONS \\ 5.1 Conclusions}

After presenting and analyzing data in the previous chapter, the writer makes the conclusions as follows:

1) The result of the study showed that Substitution and Cued Response Drills Technique works effectively in improving students' vocabulary. The improvement could be seen from the students' mean score of pre test was 45.37, formative test was 58.28 and post test was 70.12. In addition, based on the Minimum Mastery Criteria, it showed that students' score percentage of pretest was $9.37 \%$ or only 3 students got point $\geq 70$, formative test was $31.25 \%$ or 10 students got point $\geq 70$, and post test was $56.25 \%$ or 21 students got point $\geq 05$. In conclusion, Substitution and Cued Response Drills Technique was a suitable and beneficial technique in improving students' vocabulary.

2) The students' responses were very good. They agreed with application of Substitution and Cued Response Drills Technique in teaching learning vocabulary. They were interested and enthusiastic in learning vocabulary after being taught by using Substitution and Cued Response Drills Technique. It could be seen from the resut of the observation sheet, field notes and questionnaire.

\subsection{Suggestions}

Based on the study result, the writer proposes some suggestions as follows: 1) For the English teachers

The writer suggests to the English teachers to apply Substitution and Cued Response Drills Technique to improve the students' vocabulary. However, the English teacher also should pay attention to students who are not able to study by applying Substitution and Cued Response Drills Technique in learning vocabulary. 2) For the students

The students are suggested to study hard and practice their vocabulary. They are also suggested to find out another suitable technique to learn vocabulary.

\section{BIBLIOGRAPHY}

Al-Baekani, Abdul K. 2015.The Effects of Teaching Technique and Vocabulary Mastery Towards Student's Speaking Skill. Jurnal Pendidikan Unsika, 3(1), 64-78.

Allen, Dwight W. 2000. Microteaching. Boston: Addison - Wesley Publishing.

Alqahtani,Mofareh.2015. The Importance of Vocabulary in Language Learning and How to be Taught. International Journal of Teaching and Education, 3(3), 21-34. 
Altman, Howard B. et al. 1985. Research Within Reach: Research - guided Responses to the Concerns of Foreign Language Teachers. Athens: Agee Publishers.

Best, John W \& Kahn James V. 2002. Research in Education. New Delhi: Prentice Hall of India.

Brewster, Jeanetet al. 2003. The Primary English Teacher's Guide (New Edition). London: Pearson Education Limited.

Bromley, Karen. 2004. The Language and Literacy Spectrum. New York: The New York State Reading Association.

Brown, Douglas H. 2001. Teaching by Principles An Interactive Approach to Language Pedagogy (2nd Ed). San Francisco: San Fransisco State University.

Cain, Kate. 2010. Reading Development and Difficulties. Chennai: The British Psychological Society.

Cameron, Lynne. 2001. Teaching Languages to Young Learners. Cambridge: Cambridge University Press.

Corson, David. 1997. The Learning and Use of Academic English Words. Oxford: Pergamon Press.

Hatch, Evelyn \& Cherry Brown. 1995. Vocabulary, Semantics, and Language Education. Cambridge: Cambridge University Press.

Hoffman, Thomas R. 1993. Realms of Meaning. New York: Longman Publishing.

Kemmis, Stephen \& Robin McTaggart. 1988. The Action Research. Melbourne: Deaken University.

Lado, Robert. 1964. Language Teaching: A Scientific Approach. New York: Mc Gram-Hill.

Mallery, Richard D. 1994. How to Enlarge and Improve Vocabulary. Philadelp hia: Blakiston Company.

Napa, Pieter A. 1991. Vocabulary Development Skill. Yogyakarta: Kanisius.

Nation, I.S.P. 2001. Learning Vocabulary in Another Language. Cambridge: Cambridge University Press.

Nation, Paul. 2005. Teaching Vocabulary. The Asian EFL Journal Quarterly September, 7(3), 1-9. 
Neuman, Susan B. \& Julie Dwyer. 2009. Missing in Action: Vocabulary Instruction in Pre-k. The Reading Teacher, 2 (5), 384-392.

Nunan, David. 1999. Second Language Teaching \& Learning. Boston: Heinle Publishers.

Setiyadi, Bambang Ag. 2006. Teaching English As A Foreign Language. Yogyakarta: Graha Ilmu.

Thornbury, Scott. 2002. How to Teach Vocabulary. London: Pearson Education Limited.

Walter, Jo Dee. 2004. Teaching the Use of Context to Infer Meaning: A Longitudinal Survey of L1 and L2 Vocabulary Research. Language Teaching, 3(4), 243-252.

Willis, Judy. 2008. Teaching the Brand to Read. Alexandria: Association for Supervision and Curriculum Development (ASCD).

Yashinta, Dienna et al. 2013. Increasing Students' Vocabulary Achievement by Using Substitution and Cued Response Drills. Jurnal FKIP Unila, 1(1). 